Available online at http://journal.stkip-andi-matappa.ac.id/index.php/histogram/index

Histogram : Jurnal Pendidikan Matematika 2 (2), 2018, 120-131

\title{
DESKRIPSI PEMECAHAN MASALAH MATEMATIKA BERDASARKAN LANGKAH POLYA DITINJAU DARI KEPRIBADIAN SISWA PHLEGMATIS
}

\author{
Ahmad Budi Sutrisno ${ }^{1}$, Firdha Razak ${ }^{2}$ \\ STKIP Andi Matappa ${ }^{1,2}$ \\ * Corresponding Author. Email: abudisutrisno@gmail.com \\ Received: 1 September 2018; Revised: 21 September 2018; Accepted: 27 September 2018
}

\section{ABSTRAK}

Penelitian ini merupakan penelitian kualitatif yang bertujuan untuk menggambarkan kemampuan pemecahan masalah matematika berdasarkan langkah polya pada materi SPLDV ditinjau dari kepribadian siswa tipe phlegmatis (PE). Instrumen dalam penelitian ini adalah tes kepribadian, tes pemecahan masalah matematika serta pedoman wawancara. Tes kepribadian digunakan untuk mengelompokkan siswa berdasarkan kepribadiannya, tes pemecahan masalah akan digunakan untuk menunjukkan kemampuan siswa dalam memecahkan masalah matematis berdasarkan langkah polya, dan pedoman wawancara berisi sejumlah panduan yang bertujuan mengklarifikasi jawaban dan menelusuri proses berpikir siswa secara mendalam. Data dikumpulkan melalui tes dan wawancara dan dianalisis dengan menggunakan model analisis data Miles dan Huberman. Proses penelitian mengikuti tahap-tahap: (a)merumuskan indikator pemecahan masalah matematika berdasarkan langkah polya, (b)merumuskan instrumen pendukung (tes penggolongan tipe kepribadian, tugas pemecahan masalah matematika dan pedoman wawancara) yang valid dan reliabel, (c)melakukan pengambilan subjek penelitian dengan memberikan penggolongan tipe kepribadian, (d)melakukan pengambilan data untuk mengungkap deskripsi pemecahan masalah matematika yang dilakukan oleh siswa, (e)melakukan triangulasi waktu untuk mendapatkan data yang valid, (f)melakukan analisis data pemecahan masalah berdasarkan tipe kepribadian, (g)melakukan pembahasan hasil analisis, (h)melakukan penarikan kesimpulan hasil penelitian. Hasil penelitian menunjukkan bahwa subjek phlegmatis melakukan pemecahan masalah mengikuti langkah-langkah Polya yakni: (1)memahami masalah, (2)merencanakan penyelesaian, (3)melakukan rencana penyelesaian, (4)memeriksa kembali.

Kata kunci: pemecahan masalah, langkah polya, kepribadian tipe phlegmatis

How to Cite: Sutrisno, B, A., Razak, F. (2018). Deskripsi Pemecahan Masalah Matematika Berdasarkan Langkah Polya Ditinjau Dari Kepribadian Siswa Phlegmatis. Histogram: Jurnal Pendidikan Matematika, 2(2), 120-131. doi: http://dx.doi.org/10.31100/histogram.v2i2.228

\section{Permalink/DOI:}

http://dx.doi.org/10.31100/histogram.v2i2.228

\section{PENDAHULUAN}

Matematika sekolah adalah matematika yang diajarkan di jenjang persekolahan yaitu Sekolah Dasar, Sekolah Menengah Pertama dan Sekolah Menengah Atas. Salah satu hal penting dalam belajar matematika sekolah adalah tentang pemecahan masalah. Menurut Polya (dalam Uno, 2007:31) dalam suatu pemecahan masalah terdapat 4 (empat) yang 


\section{Histogram: Jurnal Pendidikan Matematika, 2 (2), 2018 - 121}

Ahmad Budi Sutrisno, Firdha Razak

harus dilakukan, yaitu 1) memahami masalah, 2) membuat rencana pemecahan masalah, 3) melaksanakan rencana, 4) memeriksa kembali jawaban.

Berdasarkan observasi di SMA Negeri 3 Pangkep, pemecahan masalah sudah tampak dalam proses pembelajaran yang merupakan bagian dari kurikulum K13 yaitu pembelajaran berbasis masalah dimana soal-soal yang ditampilkan mencakup masalah dengan berbagai penyelesaian. Banyaknya penyelesaian soal tergantung dari perbedaan berpikir siswa. Jika proses pemecahan masalah di dalam kelas diamati dengan seksama, maka kita akan dapat menyimpulkan bahwa setiap siswa di dalam kelas selalu mempunyai perbedaan. Perbedaan tersebut paling mudah diamati dalam tingkah laku secara nyata. Seorang guru tentu pernah melihat ada siswa yang memecahkan masalah matematika secara cepat namun ternyata hasilnya tidak tepat, sementara ada siswa lain yang bekerja dengan lamban namun hasil yang ia peroleh sesuai dengan kunci jawaban. Contoh lainnya, ada siswa yang menjawab soal matematika dengan runtut sesuai algoritma pemecahan masalah, sementara siswa yang lain menjawab soal dengan langkah yang terlihat tidak runtut, namun jawaban diperoleh keduanya adalah jawaban yang sama, yakni jawaban yang benar.

Perbedaan sifat dan perilaku tiap individu mempengaruhi output mereka ketika memecahkan masalah karena orang satu dengan yang lain berbeda dalam menerima informasi, memproses informasi dan cara menindaklanjuti masalah. Karena perbedaan kepribadian yang dimiliki seseorang, mereka tidak mungkin memecahkan masalah dengan pendekatan dan pengambilan keputusan dengan cara yang sama siswa, maupun guru terjadi karena pengaruh dari kepribadian yang berbeda-beda. Littauer telah membagi kepribadian manusia menjadi 4 tipe kepribadian, yakni sanguinis, melankolis, koleris dan phlegmatis. Setiap siswa di dalam kelas kita pasti memiliki minimal 1 dari kepribadian ini atau perpaduan 2 hingga 3 kepribadian tersebut (Zainal Abidin, 2014: 4).

Dalam penelitian ini akan dibahas berdasarkan kepribadian siswa berdasarkan tipe phlegmatis. Siswa phlegmatis bekerja dengan menggunakan strategi yang biasa ia lakukan, tanpa melakukan usaha untuk menggunakan strategi yang lain dari biasanya. Siswa phlegmatis adalah pemberi keseimbangan besar bagi keseluruhan kelas yang mampu melihat bahwa ada sesuatu yang tidak penting untuk dilakukan, dan dalam jangka panjang itu memang tidak benar-benar penting. Sebagai siswa, anak phlegmatis adalah administrator yang baik untuk setiap tugas. Hal ini dikarenakan mereka dapat berkomunikasi dengan baik terhadap semua teman dan memiliki kemampuan mengurus 
administrasi. Kemampuan anak phlegmatis untuk menjalankan administrasi berdasarkan keinginannya untuk menyesuaikan diri dan bukan membuat masalah dalam kelas. Di samping pandangan yang objektif pada orang lain tanpa harus ikut terlibat dalam kegiatan.

Adapun indikator kepribadian siswa berdasarkan tipe phlegmatis adalah sebagai berikut:

1. Phlegmatis suka menghadapi persoalan dengan santai dan secara bertahap.

2. Memiliki kemampuan untuk tetap tenang ketika menghadapi masalah yang begitu berat.

3. Sebagai siswa, anak phlegmatis adalah administrator yang baik untuk setiap tugas.

4. Mereka dapat berkomunikasi dengan baik terhadap semua teman dan memiliki kemampuan mengurus administrasi.

5. Sebagai suatu kelompok, siswa phlegmatis lebih suka mendengarkan dibanding berbicara.

Berdasarkan pemaparan ini, penulis ingin meneliti lebih jauh tentang "Deskripsi Kemampuan Pemecahan Masalah Matematika Berdasarkan Langkah Polya Ditinjau Dari Kepribadian Siswa Tipe phlegmatis".

\section{METODE PENELITIAN}

Jenis penelitian ini adalah penelitian deskriptif kualitatif yaitu mendeskripsikan data hasil pengamatan tentang pemecahan masalah matematis berdasarkan tipe kepribadian yang dimiliki siswa. Indikator pemecahan masalah mengacu pada langkah yang diajukan Polya (1957), yaitu: (1) understand to the problem, (2) make a plan, (3) carry out our plan, dan (4) look back at the completed solution. Sedangkan kepribadian siswa mengacu pada kategori yang dibuat oleh Littauer (1996) yaitu sanguinis, melankolis, kholeris dan phlegmatis. Akan tetapi dalam penelitian ini dibatasi hanya pada tipe phlegmatis.

Penelitian ini dilaksanakan di SMA Negeri 3 Pangkep dengan calon subjek penelitian siswa kelas X IPA 2 sebanyak 23 siswa. Instrumen yang digunakan dalam penelitian ini yaitu tes kepribadian, tes pemecahan masalah matematika serta pedoman wawancara. Dalam menentukan subjek dalam penelitian ini, calon subjek penelitian diberikan tes penggolongan tipe kepribadian. Hasil tes tertulis penggolongan tipe kepribadian ini dijadikan dasar untuk pengambilan subjek penelitian yang dipilih berdasarkan perolehan skor tes. Seorang siswa dikatakan termasuk pada kategori 
kepribadian tertentu jika ia mendapatkan skor $\geq 14$ pada item-item kepribadian bersangkutan (Zainal Abidin, 2014: 52).

Proses pengumpulan data dalam penelitian ini akan dilakukan melalui Tes Pemecahan Masalah Soal SPLDV dan wawancara. Siswa diminta untuk menulis dan menyampaikan apa yang dipikirkan ketika menyelesaikan masalah matematika, kemudian diwawancarai diminta menceritakan secara rinci aktivitasnya dalam menyelesaikan soal tersebut.

Untuk mendapatkan kevalidan data, peneliti menggunakan triangulasi metode yaitu, dengan memadukan antara teknik tes dan wawancara. Data yang terkumpul melalui kedua teknik tersebut kemudian ditinjau sifat konsistensinya. Data yang konsisiten/relatif sama adalah data yang valid, dan dilanjutkan dengan proses analisis data (Sugiyono, 2008: 337-345).

\section{HASIL PENELITIAN DAN PEMBAHASAN}

\section{A. Hasil Penelitian}

1. Paparan Data Hasil Pemecahan Masalah SPLDV Nomor 1

Berikut ini adalah soal dan hasil tugas pemecahan masalah subjek Phlegmatis (PE) pada Masalah SPLDV nomor 1

Soal :

Afi membeli 4 buah penggaris dan 2 buah penghapus di sebuah toko alat tulis dengan harga Rp 10.000,-. Jika Afi kembali membeli 3 buah penghapus dan 8 buah penggaris di toko yang sama dengan harga Rp 19.000,-. Maka berapakah harga dari 2 buah penggaris dan dua buah penghapus jika Afi membeli kembali di toko tersebut . Hasil tugas pemecahan masalah subjek ditampilkan sebagai berikut : 
Histogram: Jurnal Pendidikan Matematika, 2 (2), 2018 - 124

Ahmad Budi Sutrisno, Firdha Razak

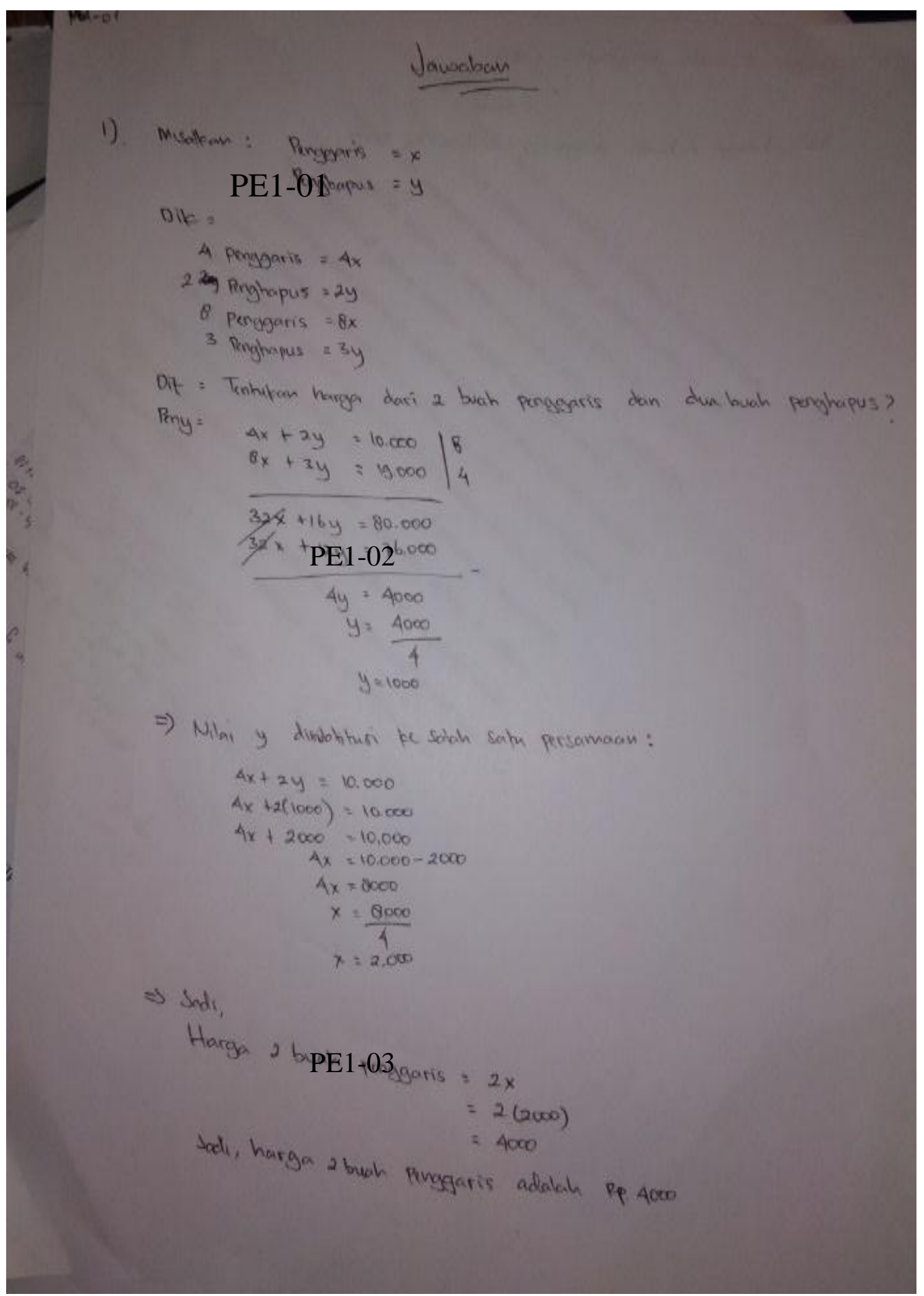

Gambar 1. Jawaban Nomor 1 Pemecahan Masalah Subjek Phlegmatis

2. Paparan Data Hasil Pemecahan Masalah SPLDV Nomor 2

Soal :

Tiga tahun yang lalu umur Sandi empat kali umur Uno. Tiga tahun yang akan datang umur 
Histogram: Jurnal Pendidikan Matematika, 2 (2), 2018 - 125

Ahmad Budi Sutrisno, Firdha Razak

Sandi hanya dua kali umur Uno. Berapa tahunkah umur Sandi dan umur Uno?

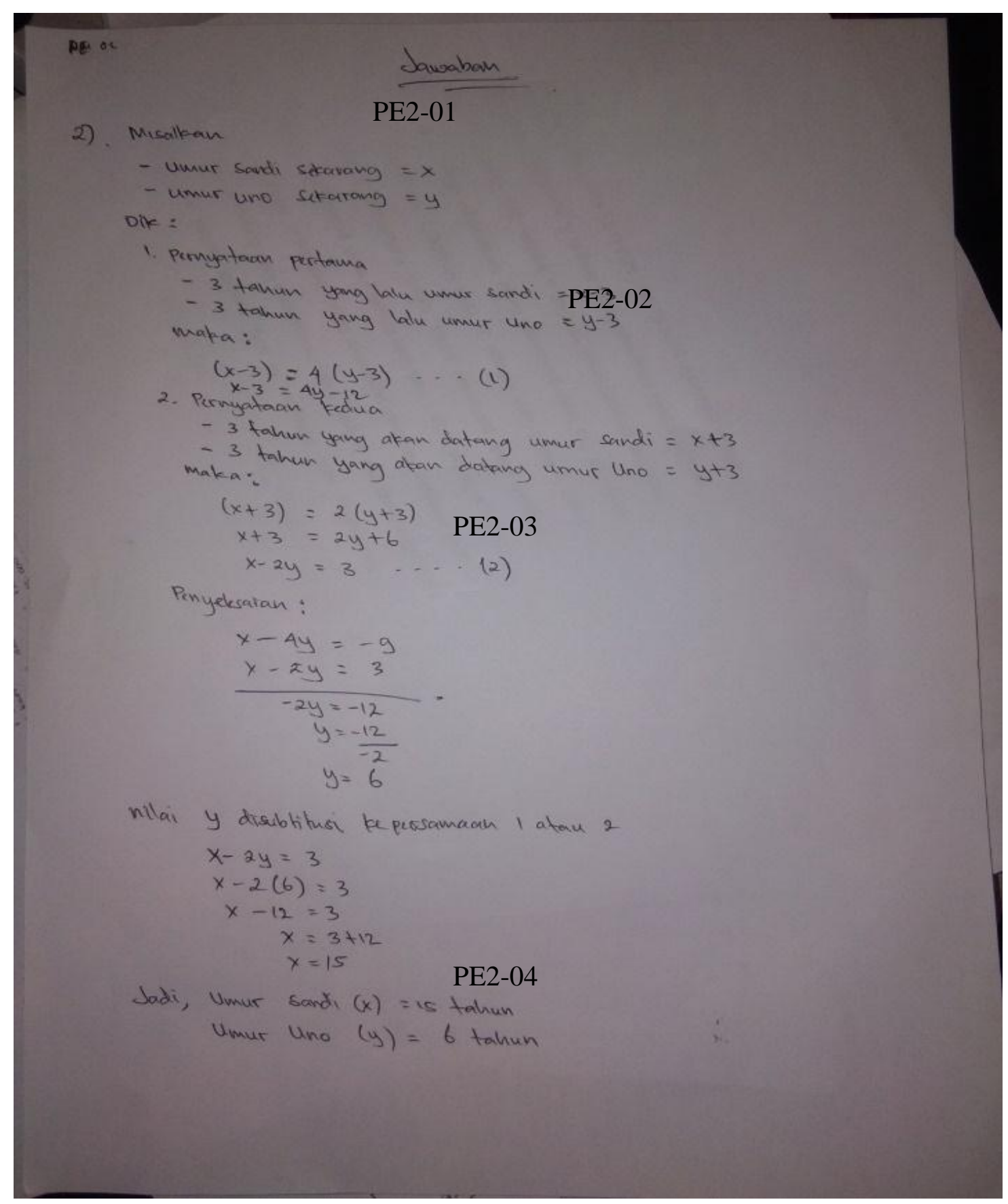

Gambar 2. Jawaban Nomor 2 Pemecahan Masalah Subjek Phlegmatis 
Histogram: Jurnal Pendidikan Matematika, 2 (2), 2018 - 126

Ahmad Budi Sutrisno, Firdha Razak

Tabel 1. Perbandingan Data Pemecahan Masalah SPLDV Nomor 1 dan Nomor 2 Subjek Phelgmatis (PE) pada Setiap Tahapan

Masalah SPLDV Nomor 1

Masalah SPLDV Nomor 2

\begin{tabular}{|c|c|}
\hline \multicolumn{2}{|c|}{ Memahami Masalah } \\
\hline $\begin{array}{l}\text { Pada tahapan ini yaitu: (a) } \\
\text { Subjek cenderung } \\
\text { menguraikan informasi pada soal } \\
\text { menjadi hal-hal yang diketahui dan } \\
\text { ditanyakan (PE-01). Subjek juga dapat } \\
\text { menceritakan kembali masalah pada } \\
\text { soal dengan bahasanya sendiri (PE1- } \\
\text { 001) }\end{array}$ & $\begin{array}{l}\text { Pada tahapan ini yaitu: (a) Subjek } \\
\text { cenderung menguraikan informasi pada } \\
\text { soal menjadi hal-hal yang diketahui dan } \\
\text { ditanyakan dan menjelaskan hubungan } \\
\text { antara hal-hal tersebut (PE2-W01), (PE2- } \\
\text { W02) dan (PE2-W06). }\end{array}$ \\
\hline Membuat Renca & Pemecahan Masalah \\
\hline $\begin{array}{l}\begin{array}{l}\text { Pada tahan ini yaitu: (a) } \\
\text { Subjek }\end{array} \\
\text { menggunakan simbol-simbol aljabar } \\
\text { untuk memisalkan harga Penggaris } \\
\text { dan harga Penghapus pada soal dan } \\
\text { menjelaskan proses penyusunan } \\
\text { kedua persamaan linear berdasarkan } \\
\text { situasi soal (PE1-001) (b) Subjek } \\
\text { cenderung mengubah situasi soal ke } \\
\text { dalam persamaan linear dua variabel } \\
\text { (PE2-W01) }\end{array}$ & $\begin{array}{l}\text { Pada Tahapan ini yaitu: (a) Subjek } \\
\text { cenderung memisalkan umur lelaki dan } \\
\text { umur Uno ke dalam penggunaan variabel } \\
\text { x dan y (PE2-W05), (PE2-W06) dan } \\
\text { (PE2-W09). (b) Subjek cenderung } \\
\text { mengubah situasi soal ke dalam } \\
\text { persamaan linear dua variabel (PE2- } \\
\text { W11) dan (PE2-W13), namun } \\
\text { mengalami kesulitan dalam menyusun } \\
\text { persamaan dari soal cerita. Kendala } \\
\text { utama adalah mengubah dari bahasa } \\
\text { verbal ke dalam simbol matematika } \\
\text { (PE2-W15). }\end{array}$ \\
\hline
\end{tabular}

\section{Melaksanakan Rencana}

Pada tahapan ini yaitu: (a) Untuk Pada tahapan ini yaitu: (a) Untuk menentukan nilai-nilai variabel dari menentukan nilai-nilai variabel dari persamaan yang ada, subjek persamaan yang ada, subjek membuat menerapkan metode eliminasi dan rencana pemecahan masalah dengan substitusi (PE1-02). (b) Subjek menerapkan metode eliminasi dan 
Histogram: Jurnal Pendidikan Matematika, 2 (2), 2018 - 127

Ahmad Budi Sutrisno, Firdha Razak

\begin{tabular}{lll}
\hline \multicolumn{2}{c}{ Masalah SPLDV Nomor 1} & \multicolumn{3}{c}{ Masalah SPLDV Nomor 2} \\
\hline cenderung menjelaskan secara umum & substitusi (PE3-MM-003). (b) Subjek \\
langkah-langkah penggunaan metode & cenderung tidak mengubah persamaan \\
eliminasi dan substitusi dalam & yang ia buat ke dalam bentuk umum, \\
menentukan nilai kedua variabel & variabel-variabel masih dituliskan secara \\
(PE1-004). (c) Subjek menjelaskan & terpisah pada dua ruas yakni ruas kiri dan \\
bahwa masalah ini bisa diselesaikan & ruas kanan untuk selanjutnya \\
dengan menggunakan metode & diselesaikan secara eliminasi (PE2- \\
eliminasi saja, tanpa menggabungkan & W18). \\
dengan metode substitusi (PE-008) (d) & \\
Kesulitan yang ditemui subjek dalam \\
menyelesaikan soal adalah ketika \\
melakukan operasi pembagian dan \\
perkalian (PE1-005).
\end{tabular}

\begin{tabular}{|c|}
\hline Memeriksa Kembali Jawaban \\
\hline $\begin{array}{lll}\text { Pada tahapan ini yaitu: (a) Subjek } & \text { Pada tahapan ini yaitu (a) } & \text { Subjek } \\
\text { tidak menuliskan proses pengujian } & \text { menguji kebenaran jawaban yang } \\
\text { kebenaran jawaban yang diperolehnya } & \text { diperolehnya pada kertas buram sebelum } \\
\text { pada lembar jawaban, namun } & \text { menuliskannya di lembar jawaban. } \\
\text { menuliskannya di lembar buram. } & \text { Subjek memeriksa jawaban dengan } \\
\text { Subjek memeriksa jawaban dengan } & \text { melakukan substitusi nilai variabel x dan } \\
\text { melakukan substitusi nilai variabel x y yang diperoleh ke dalam salah satu } & \text { y } \\
\text { dan y yang diperoleh ke dalam salah } & \text { persamaan. (PE2-W21) } \\
\text { satu persamaan. (PE1-007). } & \end{array}$ \\
\hline
\end{tabular}

(Sumber : Data Primer, Tahun: 2018)

Dari deskripsi ini terlihat bahwa subjek Phlegmatis (PE) tidak dapat mengikuti secara lengkap langkah-langkah Polya dalam pemecahan masalah. Dalam penulisan jawaban pada lembar pemecahan masalah subjek PE hanya menuliskan langkah pemecahan masalah mulai dari memahami masalah, merencanakan pemecahan masalah, dan melaksanakan rencana. Sedangkan untuk langkah memeriksa kembali jawaban subjek tidak dapat memenuhinya pada lembar jawaban yang disediakan. 


\section{Histogram: Jurnal Pendidikan Matematika, 2 (2), 2018 - 128 Ahmad Budi Sutrisno, Firdha Razak}

\section{B. Pembahasan}

Berdasarkan tugas pemecahan masalah, subjek phlegmatis memahami soal dengan memisahkan informasi pada soal, cenderung menguraikan informasi pada soal menjadi hal-hal yang diketahui dan ditanyakan. Dalam wawancara, subjek phlegmatis dengan tenang memberikan penjelasan tentang apa yang ia pahami dari soal yang diberikan. Kekuatan subjek phlegmatis seperti yang dikatakan oleh Littauer (1996) adalah rasa tenang ketika mereka menghadapi masalah dan berbicara. Dari gaya berbicara peneliti menyimpulkan bahwa subjek merupakan tipe phlegmatis yang ekstrim. Subjek hanya menjawab dengan jawaban yang singkat, sering tanpa ditambah dengan komentar apa pun. Subjek phlegmatis secara detail menceritakan kembali masalah yang dihadapi pada soal dengan menggunakan bahasanya sendiri. Ketika diminta untuk menjelaskan apa yang ia pahami tentang masalah, subjek menjelaskan secara detail mulai dari awal proses pengerjaannya pada lembar jawaban hingga ia menemukan jawaban atas masalah yang diberikan. Dalam proses ini subjek berpikir secara asimilasi dengan mengintegrasikan informasi baru yang ia terima dengan skema yang telah ada dalam pikirannya. Subjek menunjukkan keteraturan tidak hanya pada langkah-langkah dalam penulisan pemecahan masalah di lembar jawaban, tetapi juga dari cara subjek menjelaskan apa yang ia pahami. Phlegmatis memang merupakan tipe yang tidak banyak bicara, tetapi ketika diminta untuk menjelaskan sesuatu, mereka selalu bisa menjelaskan itu secara detail.

Setelah memahami masalah, subjek cenderung menggunakan simbol-simbol aljabar untuk memisalkan hal yang diketahui pada soal. Subjek kemudian membentuk dua buah persamaan linear yang memuat variabel $\mathrm{x}$ dan $\mathrm{y}$. Dalam wawancara subjek menjelaskan bagaimana prosedur menentukan dua buah persamaan linear yang ia pilih nanti akan memberikan jawaban yang diinginkan oleh soal. Dalam proses perencanaan ini, subjek berpikir secara asimilasi. Pada persamaan yang lebih rumit, subjek membutuhkan waktu yang relatif lebih lama dalam membentuk persamaan yang sesuai dengan situasi pada soal. Meski demikian, subjek akhirnya dapat menjelaskan rencana pemecahan masalah yang ia pilih dengan lancar. Kesulitan yang dialami subjek dikarenakan pemecahan masalah dalam matematika sering melibatkan metode dan cara penyelesaian yang tidak standar dan tidak diketahui terlebih dahulu (Turmudi, 2008: 28). 


\section{Histogram: Jurnal Pendidikan Matematika, 2 (2), 2018 - 129 Ahmad Budi Sutrisno, Firdha Razak}

Rencana yang dibuat oleh subjek diaplikasikan dengan menggunakan metode eliminasi yang dilanjutkan dengan substitusi untuk menentukan nilai dari variabel $\mathrm{x}$ dan variabel y. Pada tahap pertama, subjek berusaha menemukan nilai variabel x. Subjek melakukan eliminasi pada variabel y dengan cara menyamakan koefiesien y di kedua persamaan dan mengurangkan kedua persamaan. Pada tahap kedua, subjek menstubstitusikan nilai variabel x yang ia peroleh pada tahap pertama ke dalam salah satu persamaan untuk memperoleh nilai y. Pada sistem persamaan linear yang bukan merupakan bentuk persamaan umum, subjek langsung melakukan eliminasi pada variabel yang sama koefisiennya tanpa mengubah bentuk persamaan ke dalam bentuk umum $a x+b y=c$. Dengan kedua variabel tetap berada dalam ruas yang berbeda, subjek menyelesaikan sistem persamaan linear yang bentuk persamaannya telah ia buat. Pada tahap ini subjek berpikir secara asimilasi dan abstraksi. Pemecahan masalah yang dilakukan oleh subjek phlegmatis dilakukan dengan baik. Dalam keseluruhan proses melaksUnoan rencana yang ia buat, semua dilakukan tanpa melakukan kesalahan penulisan dalam lembar jawaban. Subjek phlegmatis berhati-hati dalam penulisan pemecahan masalah. Subjek menuliskan terlebih dahulu perhitungan yang ia buat dalam kertas buram dan setelah yakin bahwa jawaban yang ditulisnya benar subjek memindahkan catatan itu ke dalam lembar jawaban. Gambaran ini menunjukkan bahwa phlegmatis adalah subjek yang teratur secara administrasi. Untuk menghindari adanya kesalahan dalam lembar yang akan dikumpulkan, subjek terbiasa menuliskan apa yang ada dalam pikirannya pada kertas buram.

Pada saat melakukan pemeriksaan kembali terhadap jawaban yang diperoleh, subjek melakukan hanya dengan melihat ulang langkah-langkah pengerjaan soal, namun tidak menuliskannya di lembar jawaban. Subjek menggunakan kemampuan proseduralnya untuk melakukan pemeriksaan kembali tanpa menggunakan catatan lain. Subjek merasa yakin bahwa jawaban yang ia peroleh sudah benar karena prosedurnya sesuai dengan yang ia pahami. 


\section{KESIMPULAN DAN SARAN}

\section{A. Kesimpulan}

Berdasarkan hasil penelitian dan pembahasan yang dilakukan, maka diperoleh kesimpulan dalam penelitian ini, sebagai berikut:

1. Deskripsi pemecahan masalah matematis siswa dengan tipe phlegmatis adalah sebagai berikut.

a. Memahami Masalah

Subjek menguraikan informasi pada soal menjadi hal-hal yang diketahui dan ditanyakan dan menuliskan secara eksplisit pada lembar jawaban. Subjek juga dapat menceritakan kembali masalah pada soal dengan bahasanya sendiri.

b. Membuat Rencana Pemecahan Masalah

Subjek membuat persamaan matematika berdasarkan situasi pada soal yang memuat variabel $\mathrm{x}$ dan variabel y kemudian membentuk persamaan linear dua variabel.

c. Melakukan Rencana

Subjek menentukan nilai variabel $\mathrm{x}$ dan $\mathrm{y}$ pada kedua persamaan dengan menggunakan metode eliminasi dan substitusi. Subjek ditemui subjek dalam menyelesaikan soal adalah ketika melakukan operasi pembagian dan perkalian.

d. Memeriksa Kembali Jawaban

Subjek melakukan menguji kebenaran jawaban yang diperolehnya pada kertas buram sebelum menuliskannya di lembar jawaban.

\section{B. Saran}

Berdasarkan kesimpulan yang di atas, maka disarankan hal-hal sebagai berikut:

1. Hasil penelitian ini diharapkan dapat menjadi rekomendasi bagi para guru bahwa keberhasilan siswa dalam belajar matematika bukan hanya bergantung dari aspek kognitif, melainkan juga dipengaruhi oleh aspek psikologis.

2. Guru yang mengajar siswa phlegmatis perlu membiasakan siswa untuk memecahkan masalah matematika yang berupa soal cerita.

3. Untuk penelitian yang relevan, agar meneliti dengan subjek pada tiap kepribadian berdasarkan gender, dengan verifikasi berikut: 1) materi pelajaran yang melibatkan proses pemecahan masalah yang lebih rumit, dengan pengaitan pada materi sistem 
Histogram: Jurnal Pendidikan Matematika, 2 (2), 2018 - 131

Ahmad Budi Sutrisno, Firdha Razak

persamaan linear 3 variabel. 2) merevisi kembali pedoman wawancara yang langsung mengungkapkan proses berpikir siswa dalam pemecahan masalah secara mendetail dan terstruktur.

\section{DAFTAR PUSTAKA}

Abidin, M, Z. (2014). Deskripsi Pemecahan Masalah Matematis Materi Spldv Berdasarkan Kepribadian Siswa. Tesis tidak diterbitkan. Makassar: PPs Universitas Negeri Makassar

Littauer, F. (1996). Personality Plus. Jakarta : Bina Aksara Rupa.

Polya, G. (1957). How to Solve It : A new Aspect of Mathematical Model. New York : Garden City.

Sugiyono. (2008). Metode Penelitian Pendidikan. Pendekatan Kuantitatif, Kualitatif, dan $R \& D$. Bandung: Alfabeta.

Turmudi. (2008). Landasan Filsafat dan Teori Pembelajaran Matematika. Jakarta: Leuser Cita Pustaka.

Uno, H, B. (2007). Model Pembelajaran: Menciptakan Proses Belajar Mengajar yang Kreatif dan Efektif. Jakarta: Bumi Aksara.

Yuwono, A. (2010). Profil Siswa SMA dalam Memecahkan Masalah Matematika Ditinjau dari Tipe Kepribadian. Tesis tidak diterbitkan. Surakarta: Universitas Sebelas Maret. 